\title{
Mexico City, cradle of the first radiologic study in the Mexican Republic
}

\author{
Carlos Adrián De Alba-Guevara, ${ }^{1}$ Fernando De Alba-Quintanilla² and Gustavo Casián-Castellanos ${ }^{3}$
}

${ }^{1}$ Department of Imaging, Hospital MEDISCIN, Ciudad Valles, San Luis Potosí; ${ }^{2}$ Centro de Radiodiagnóstico, Ciudad Valles, San Luis Potosí; ${ }^{3}$ Secretaría de Salud, Hospital Juárez de México, Department of Radiology and Imaging, Ciudad de México. Mexico

\begin{abstract}
In August 1896, engineer Gilberto Crespo y Martinez published an article where he presented two radiographies produced by Roberto Jofre and Fernando Ferrari Perez. This corresponded to the two first radiographs carried out in the Mexican Republic, two months earlier than those produced in the city of San Luis Potosi on October 24 and the one by Doctor Tobías Núñez at the Juarez Hospital on October 19 that same year.
\end{abstract}

KEY WORDS: Radiology. History of medicine. Technological advances in medicine.

\section{Introduction}

Roentgen discovered X-rays in November 1895 when he was studying the mysterious cathode rays. For this, he used simple instruments that could be found in any physics or electricity laboratory, no matter how modest, or that could be easily acquired in stores, as they were commonly used materials. This way, with a simple Crookes tube, which had a Ruhmkorff coil as electric power source, and a fluorescent screen used to identify the cathode rays outside the tube, made with a cardboard sheet covered with barium platinocyanide crystals, was that he discovered $\mathrm{X}$-rays. To demonstrate them, he used common photo paper and obtained photographs of several objects. ${ }^{1}$

Roentgen's discovery was published on December 28, 1895 in the Würzburg Physical-Medical Society Bulletin, a modest publication. He sent reprints of the article and photographs to several scientists (apparently 90 letters), and on January 23 next year he gave a lecture at the Würzburg Physical-Medical Society. The dissemination of the discovery was very quick and without barriers, to such an extent that, in 1896, more than 1000 scientific papers and 48 books on $X$-rays were published. ${ }^{2}$ The first news arrived to Mexico via a telegram, the text of which appeared in the San Luis Potosí newspaper El Estandarte. ${ }^{3}$

At that time, building an equipment to make radiographs was very simple, and that was quickly understood by physicists and by those with knowledge on electricity. An electric power source was required, which could be provided by a battery formed by several interconnected Leyden bottles (the most elementary power source), a simple electrostatic machine, an electric generator (such as the Ruhmkorff coil), a Pixii dynamo or directly from electric current, ${ }^{4}$ as well as a vacuum tube with electrodes to generate high voltage currents -the most widely used was Crookes tube; however, by 1986, a great variety of these devices had been built; in an article published by La Nature, 32 different X-ray tubes are illustrated, ${ }^{5}$ as well as a fluoroscopic screen, which could be handcrafted or industrially manufactured, such as the cryptoscope, Magendie's skiascope or the popular Edison's vitascope. Finally, the images could be printed on commercial photographic paper or on crystals or celluloid coated with silver bromide photosensitive emulsion. ${ }^{6}$
Correspondence:

Carlos Adrián De Alba-Guevara

E-mail: carlosadrian@hotmail.com
Date of reception: 09-05-2017

Date of acceptance: 15-01-2018

DOI://dx.doi.org/10.24875/GMM.M18000184
Gac Med Mex. 2018;154:449-453

Contents available at PubMed www.gacetamedicademexico.com 


\section{First radiographs in the Mexican Republic}

Without a doubt we can claim that the first radiographs that were obtained in the Mexican Republic were practiced in Mexico City, without to this moment being able to specify where, possibly in a medical electricity cabinet. To affirm such assumption, we have the photograph of two radiographs and the work where this fact is mentioned. The history of these radiographs could be reconstructed thanks to an article that was rescued in November 2016, in an old bookstore located in the street of Donceles, Mexico City.

Until now, it had been accepted that the first radiological studies and the first radiographs were carried out in October 1896 in the city of San Luis Potosí and a few days later at Hospital Juárez de Mexico.

According to El Oficial de San Luis Potosí, on October 24, 1896, in the city of San Luis Potosí "[...] experiences have started being carried out with the purpose to see through opaque bodies... "? No evidence was left from those experiments. The equipment had been purchased in Berlin on an unspecified date: it was a "Roentgen machine" that by default came with a Ruhmkorff coil, a Crookes tube and an Edison fluoroscope.

Some reports initially disseminated by the press often distorted its usefulness and uses; it came to be believed that Roentgen's rays had an application in ordinary photography. Engineer Luis Espinosa y Cuevas, a member of the San Luis Potosí oligarchy and who had sufficient economic resources, acquired a promising Roentgen machine for the equivalent of about one hundred dollars for his two brothers, who were fond of photography. He shipped it in some port in Europe with Mexico as destination. It arrived to the port of Tampico on October 3, 1896 and, without customs problems of any kind, it was remitted by rail to the City of San Luis Potosí. ${ }^{8}$

When the X-ray equipment was already in the city of San Luis, Mr. Javier Espinoza y Cuevas, brother of Don Luis, began to make some photographic experiments and, on occasions, he lent the equipment to some locally selected doctor. Thus it was possible to carry out some medical radiological study.

The above information was initially published in Archivos de Historia Potosina in June 1982 and later several articles were published that spread information about $\mathrm{X}$-rays application in various contingencies in the city of San Luis Potosí. ${ }^{9-13}$ Curiously, of all the referred experiences, there is only an undated radiograph of an ankle and foot with footwear that has become an icon in radiology, and that in the article entitled "San Luis Potosí, cradle of Mexican radiology" is described as: "possibly the first radiograph taken in San Luis Potosí (and in the Republic), at Espinosa and Cuevas, Bros. study." This is how it was accepted that the first radiological studies were performed in San Luis Potosí. ${ }^{14}$

Prior to 1982, known history indicated that the first radiograph in the republic had been obtained by Dr. Tobias Núñez on October 29, 1896, at Hospital Juárez in Mexico City. This is described by Dr. Amador Zafra in his thesis "Some applications of X-Rays to surgery and medicine ", ${ }^{15}$ who closely experienced the event. The first radiograph showed the dislocation of an elbow.

This was the chronicle we radiologists of the old generation knew and that was disseminated in several articles relative to the history of radiology, of mandatory consultation for those interested in the subject. ${ }^{16,17}$ However, in Dr. Zafra's thesis there is an interesting paragraph:

\footnotetext{
...Without getting into great details, we will quickly indicate the experimental technique used to produce $X$-rays. The necessary material consists of a source of electrical energy, a transformer and a Crookes tube; the first one is generally composed of a battery of eight to ten accumulators that provide a 16 to 20 -volt current; the most widely used transformer is Ruhmkorff coil..., and as for the radiographic tube or ampule, there are in many forms... This is the gear employed at Dr. Roberto Jofre's Institute of Medical Electricity...
}

Doctor Zafra makes clear reference of the existence of an X-ray equipment by means of which radiographs were obtained and it can be speculated that the elbow radiograph was not the first one he performed ${ }^{15}$

\section{Rectifying history}

Interested in the history of radiology in Mexico, we have researched in numerous public and private libraries and in many other places. In one of the old bookstores of the street of Donceles, in Mexico City, in November 2016 we found a small hand-made book, where the reprint of an article entitled "On X-rays" is included (Fig. 1).

This work was prepared by engineer Gilberto Crespo y Medina and read at the Academy of Physical and Natural Exact Sciences, corresponding to the Royal Academy of Madrid, in August 1896. In this article, engineer Crespo y Martínez makes a full description of the knowledge there was on the newly-discovered 


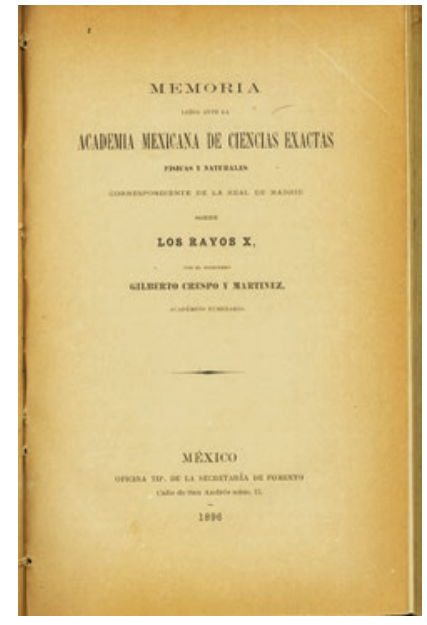

Figure 1. Cover of the article by engineer Gilberto Crespo y Martínez entitled "On X-rays".

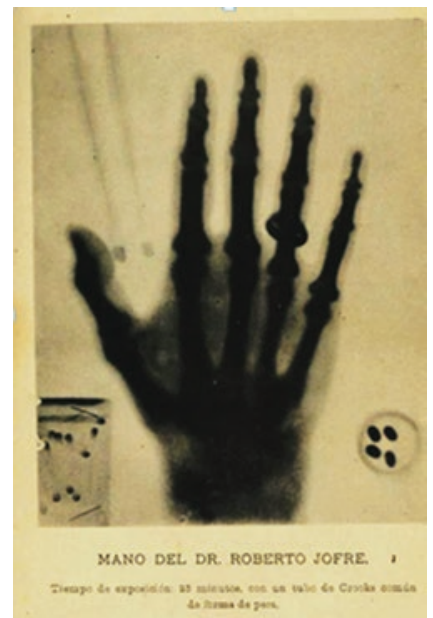

Figure 2. The caption reads: "Dr. Roberto Jofre's Hand. Time of exposure 25 minutes, with a common pear-shaped Crooks tube".

X-rays, the way to produce them and the fluoroscopic and photographic effects..$^{18,19}$ On page 17 he textually wrote:

...About X-rays origin, nature and main properties, and in regards to the way of repeating Roentgen experiences, nothing is simpler. A Crookes tube; a Ruhmkorff coil; a dichromate battery and a photographic plate with an ordinary lightproof envelope, between which and the Crookes tube the object the image of which is to be obtained should be placed. With these so simple elements, Professors Fernando Ferrari and Roberto Jofre have obtained among us the images they have been so kind to provide to me, and which I have the pleasure of showing you, of Dr. Jofre's hand, some pills inside a box, the graphite of a pencil and the matches enclosed in the respective box...

Mexico, August 1896

The penultimate page of the article corresponds to the picture of a radiograph of Dr. Roberto Jofre's hand, where in addition a box of matches and a bottle of pills are observed (Fig. 2).

On the last page there is a collage with the photographs of the drawing of an M. E. Colardeu tube and three radiographs of several objects. A repeated image with the radiograph of several objects (dip pen nibs, cogwheels) that was obtained with two different tubes, an M. E. Colardeau and a Crookes tube, draws the attention, and there is a remarkable difference in sharpness between the images (Fig. 3). Engineer Crespo y Martínez points out that the radiographs were provided by engineer Fernando Ferrari Pérez and Dr. Roberto Jofre.

Having obtained the radiograph of an object with two different $\mathrm{X}$-ray tubes means that they already had several tubes.

We must conclude that if Dr. Jofre was the one who was dedicated to medical electricity, these tubes were his property and he was the one who provided the $X$-ray equipment for these experiments, probably an equipment built by himself. We assume that engineer Ferrari Pérez, who was interested in photography, was in charge of developing the radiographs.

Now we know that engineer Gilberto Crespo y Martínez (1852-1916) was born in the port of Veracruz and studied in Xalapa, Puebla and, finally, in Mexico City, where he graduated as an engineer at the National School of Engineers in 1879, specializing in mining and metallurgy. Since early in his career he started working in the Department of Agriculture, Mining and Trade of the Ministry of Development. President Porfirio Díaz was interested in showing the world a new face of Mexico. One of the measures was to promote science, and thus he decided to found scientific institutions and commissioned different professionals to attend and participate in the main international scientific congresses and contests, trying to create conditions that allowed the scientific community increasing their knowledge.

International exhibitions had become the showcase of modernity; there, the vertiginous advance of science and technology was shown. Díaz appointed engineer Crespo y Martínez to attend the International Exhibition of New Orleans (1884), to contact scientists from other countries and catch up on the current state of science; it was also a good idea taking advantage of the opportunity for scientists to have political representation. ${ }^{20-23}$

During his attendance at the New Orleans exhibition, engineer Crespo y Martinez was appointed temporary consul in Havana and later official 


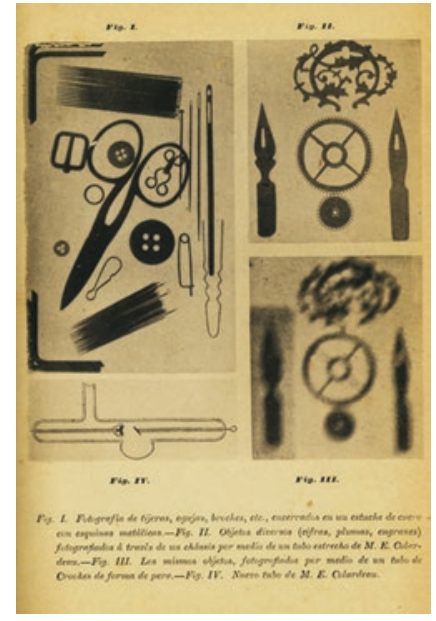

Figure 3. Second and last radiograph, on an unnumbered page of the article "On X-rays". The caption reads: "Figure II. Diverse objects (ciphers, nib pens, cogwheels) photographed through a frame by means of a narrow M. E. Colardeau tube. Figure III. Same objects, photographed with a pear-shaped Crookes tube".

representative of Mexico in Cuba. In 1886 he returned to Mexico and began to actively participate in politics and, between 1886 and 190,2 he was elected congressman, representing Veracruz. In 1889, as a member of the Mexican Commission, he attended the World's Fair at Paris, and between 1892 and 1899 he was in the top of political power, he was Undersecretary of the Ministry of Development. .,11 $^{11}$

Engineer Fernando Ferrari Pérez (1857-1933) was a former student of the National Preparatory School and of the Special School of Engineers, he was a physics and chemistry teacher, naturalist by vocation and photographer by conviction. Initially, he was member of the Geographical-Exploring Commission belonging to the Ministry of Development, the original purpose of which was to prepare a general map of the republic and organize topographic knowledge about the country. He became head of the Natural History Section of this Commission. In 1884, the government ordered the Commission to participate in international exhibitions, such as the one at New Orleans, and Ferrari made careful zoological catalogs and numerous photographic reproductions of plants and animals, by means of which he formed a great collection. Towards 1887 he was appointed director of the National Museum of Mexican Plants. He participated in the World's Fairs of New Orleans, Paris in 1889 and Chicago in 1894. ${ }^{24-26}$ With no doubt, in this journey he established contact with engineer Crespo.

Dr. Roberto Jofre had completed his studies at the School of Medicine of Mexico and he presented his exit examination in 1889; his graduation thesis is entitled New Rheostat ${ }^{27}$ and is related to medical electricity. From the beginning of his professional practice he expressed his interest in medicine-applied electricity. After having graduated he entered as an assistant (preparer) at the National Medical Institute, which until 1888 was named Institute of Biology, and the purpose of which was to carry out an inventory of the medicinal flora of the Mexican soil. He was assigned to the Third Section, or Physiology, which was responsible for the study of the physiological effects of drugs produced by medicinal plants. In the department of that section, observations on toxicity of plants were made, which were complemented with studies with electro-medical recording devices: cardiographs, myographs, etc., which were handled by Dr. Jofre. ${ }^{27-30}$ In 1889, Dr. Jofre published a work entitled New rheostat, built to obey the following principle in therapeutic applications of electricity and, years later, in 1893, The study of reflexes, both published in El Estudio journal. ${ }^{31}$ The works of the Institute were incorporated to or depended on the Ministry of Development.

Apparently, thus was how contact was established among the varied group of scientists and politicians.

\section{References}

1. Glasser O. Dr. W. C. Rontgen. EE.UU.: Charles C. Thomas Publishers; 1972.

2. Glasser O. Wilhelm Conrad Röntgen and the early history of the Roentgen Rays. EE.UU.: Norman Publishing; 1993.

3. Telegramas del extranjero. El Estandarte. 19 de febrero de 1896. Número 1657. Página 3.

4. Glasser O. The Science of Radiology. EE.UU,: Charles C. Thomas Publishers; 1933.

5. Trevert $E$. Something about $X$ rays for everybody. The $X$ Rays Century. 1896;2:1:1-7.

6. Eisenberg RL. Radiology, An illustrated history. EE.UU.: Mosby Year Book; 1992

7. Parte no Oficial. Crónica Local. Experimentos con los rayos X. Periódico Oficial del Estado de San Luis Potosí 24 de octubre de 1896;69: 9.

8. Alcocer AA, Padrón PF, Quijano PF. San Luis Potosí cuna de la radiología mexicana. Archivos de Historia Potosina. 1982;13:1-12.

9. Alcocer AA Quijano-Y-Ramos, JM. Una aplicación de la radioscopia a la cirugía (entre1896 y 1899). Rev Med Hosp Central. 1978;2:36-38.

10. Alcocer AA. Datos para la historia de la radiología mexicana. Negatoscopio. 1985;1: 8-11.

11. Alcocer AA, Padrón PF, Quijano PF. San Luis Potosí, cuna de la radiología mexicana. Biblioteca de Historia Potosina. Serie Cuadernos 87. Academia de Historia Potosina. San Luis Potosí, 1986.

12. Quijano PF, Quijano OF. Dos joyas bibliográficas médicas potosinas. Gac Med Mex. 1986;122:55-57.

13. Quijano PF, Padrón PF, Alcocer AA. Historia de la radiología. Un antecedente potosino de la arteriografía. Rev Mex Radiol. 1987;41:39-44.

14. Stoopen ME. Los pioneros de la radiología. En: Cárdenas-De-La-Peña E. Orígenes de las Especialidades en México. México: Academia Nacional de Medicina; 1993.

15. Zafra A. Algunas aplicaciones de los rayos $X$ a la cirugía y la medicina. [Tesis]. México: Escuela Nacional de Medicina de México; 1897.

16. Alcántara HJ ¿Quiénes introdujeron, en México, los rayos X y el radio en medicina? Rev Med Mex. 1947;37:321-339.

17. Villanueva B. Datos para la historia de la radiología en México. Rev Mex Radio. 1969;23:259-274.

18. Crespo-Y-Martínez G. Sobre los rayos X. México: Oficina de la Secretaría de Fomento; 1896. 
19. Crespo-Y-Martínez G. Sobre los rayos X. En: Datos para varios estudios recogidos por Gilberto Crespo y Martínez. Volumen IV. México: Secretaría de Fomento; 1899

20. Camacho NE. Gilberto Crespo y Martínez y su participación en la política de fomento para el México porfirista. Reflexiones a propósito de su obra dedicada a Bélgica. Revista de Estudios Históricos. 2009;49:131-168.

21. Rosenzweig G. Los diplomáticos mexicanos durante la revolución: Entre el desempleo y el exilio. Historia Mexicana. 2012;61:1461-1523.

22. Camacho-Navarro E. Gilberto Crespo y Martínez, un operador de la diplomacia de México en la Cuba republicana (1902-1906). Rev Mex Po Ext. 2008;(84):93-120. Disponible en. https://revistadigital.sre.gob.mx/ images/stories/numeros/n84/camacho.pdf

23. Crespo y Martínez G. Datos para varios estudios. Volumen 3 México: Secretaría de Fomento; 1899 .

24. Diccionario Porrúa de historia, biografía y geografía de México. Tomo I. México: Porrúa; 1986.
25. Enciclopedia de México. Tomo V. México: SEP; 1987.

26. Wikipedia. Fernando Ferrari-Pérez. Disponible en: https://en.wikipedia. org/wiki.

7. Jofre Roberto. Nuevo Reóstato. [Tesis]. México: Escuela Nacional de Medicina; 1889.

28. Azuela LF, Guevara FR. La ciencia en México en el siglo XIX: Una aproximación historiográfica. Asclepio. 1998;50:77-105.

29. Hinke N, Chazaro L. El Instituto Médico Nacional. La política de las plantas y los laboratorios a fines del siglo XIX. México: Universidad Nacional Autónoma de México/Cinvestav; 2012.

30. Marcial-Avendaño A. Antecedentes del Instituto Médico Nacional y los primeros años de trabajo de la Sección $3^{\mathrm{a}}$ de Fisiología. Bol Hist Fil Med. 2007;10:21-27.

31. Rodríguez-De Romo AC. Fisiología mexicana en el siglo XIX: La investigación. Asclepio. 1997;49:133-145. 